J. Lake Sci. (湖泊科学), 2014, 26(3): 473-480

http://www. jlakes. org. E-mail : jlakes@niglas.ac.cn

(C) 2014 by Journal of Lake Sciences

\title{
江苏省石梁河水库高分辨率沉积速率变化及环境意义
}

\author{
张云峰, 张振克 ${ }^{* *}$,王万芳, 张凌华, 陈影影,徐华夏 \\ (南京大学地理与海洋科学学院海岸与海岛开发教育部重点实验室,南京 210093)
}

\begin{abstract}
摘 要: 石梁河水库是江苏省最大的人工湖泊. 开展水库沉积速率研究, 对认识水库环境变化具有重要意义. 本文对石梁 河水库沉积物岩芯粒度组成特征进行了分析, 表明沉积物以黏土质粉砂和粉砂质黏土为主, 从底部向上呈明显的变细趋 势, 并记录了 1970 年的强降雨事件. 采用 ${ }^{137} \mathrm{Cs}$ 同位素测年分析, 得到 1963 年和 1986 年两个时标. 通过石梁河水库的沉积 年代序列, 推算出平均沉积速率: $1963-1970$ 年为 $10.85 \mathrm{~cm} / \mathrm{a}, 1970-1986$ 年为 $3.81 \mathrm{~cm} / \mathrm{a}, 1986-2005$ 年为 $1.32 \mathrm{~cm} / \mathrm{a}$. 对比粒度沉积特征和流域降水记录,粗颗粒物质和降雨量的变化趋势基本相同, 沉积物粒度组成特点直接反映了沉积时 的降水、水动力搬运强度等信息. 在河川来水来沙、坝前水位变化和地形等条件下,石梁河水库表现为三角洲淤积, 且沉 积速率逐渐变缓,符合水库淤积的一般规律. 此外, 石梁河水库上游建设的众多大型水库, 拦截了大量泥沙, 也使得沉积 速率呈现减小趋势.
\end{abstract}

关键词: 石梁河水库; 沉积速率; ${ }^{137} \mathrm{Cs}$ 测年; 环境变化

\section{The changes of sedimentation rates and the environmental significance based on high resolution cores in Shilianghe Reservoir, Jiangsu Province}

ZHANG Yunfeng, ZHANG Zhenke, WANG Wanfang, ZHANG Linghua, CHEN Yingying \& XU Huaxia

(Key Laboratory of Coast and Island Development of Ministry of Education, School of Geographic and Oceanographic Sciences, Nanjing University, Nanjing 210093, P. R. China)

Abstract: Shilianghe Reservoir is the largest artificial lake in Jiangsu Province. It is very important to study the sedimentary rates of the reservoir in order to understand the environmental change in the river basin. ${ }^{137} \mathrm{Cs}$ technique is used to date a sediment core collected from Shilianghe Reservoir. Two distinct ${ }^{137}$ Cs peaks are identified in the core, which are ascribed to the abundant fallouts occurring in 1963 and 1986. The grain size analysis indicates that clayey silt and silty clay are the main sedimentary types with a trend of gradually fining from the bottom to the top, and revealed a heavy rainfall event in 1970. Sedimentary rates of the core can be divided into several distinctive stages: $10.85 \mathrm{~cm} / \mathrm{a}$ from 1963 to $1970,3.81 \mathrm{~cm} / \mathrm{a}$ from 1970 to 1986 , and $1.32 \mathrm{~cm} / \mathrm{a}$ from 1986 to 2005 . Furthermore, the environment significances were explained by using the sedimentary records. Through the comparison between grain size characteristics and historical precipitation records, the changes of coarse sediments contents and rainfall are of the similar trend, which directly reflects the information such as the intensities of rainfall and hydrodynamic transportation. Sedimentary environment of the Shilianghe Reservoir is typical deltaic under the controls of runoff and sediment transport, variations of water level and local terrain. Therefore, sedimentary rates are becoming low gradually following the general law of reservoir siltation. Furthermore, human activities have influenced the changes of sedimentary rates, such as construction of large reservoirs in the upstream of the river.

Keywords: Shilianghe Reservoir; sedimentation rates; ${ }^{137}$ Cs dating; environmental change

水库是开发利用水资源和防治水害的综合工程措施之一, 具有防洪、灌溉、发电、供水、航运、养殖、旅游 等综合效益. 自 1950s 以来,我国水库建设突飞猛进,水库数量跃居世界之首,在河流上修建水库会破坏河流

* 湖泊与环境国家重点实验室开放基金项目 (2010SKL004) 和国家自然科学基金项目 (41071006) 联合资助. 2013 04-25 收稿;2013-10-09 收修改稿. 张云峰(1980～), 男,博士研究生;E-mail : zhangyunfeng1980@ 126. com.

** 通信作者;E-mail:zhangzk@ nju. edu.cn. 
水沙条件和河床形态的平衡状态, 由于水位抬高, 流速减小, 必然造成泥沙在水库中的淤积 ${ }^{[1]}$. 田海涛等 ${ }^{[2]}$ 根据 115 座代表性水库的淤积统计资料,推算出我国水库的平均淤积比例高达 $20 \%$. 水库泥沙沉积物作为 流域物质迁移的 “汇”, 可以连续、高分辨率地记录流域环境演变和人类活动的信息, 对科学认识水库的环境 变化过程具有十分重要的作用, 已成为短尺度环境沉积学和流域土壤侵蚀、地表物质输移过程研究的重要 对象 ${ }^{[3]}$. Annandale ${ }^{[4]}$ 从河流水力学、河床形态、流域产沙和泥沙拦蓄、泥沙输运动力机制、泥沙沉积分布特 征、水库排沙和水库淤积治理等方面对水库沉积做了系统阐述, 为水库沉积的科学研究奠定了基础. 近年 来, 国内外水库环境变化研究领域正从现状特征分析向过程演变转变, 将水库沉积过程与流域环境变化结 合起来, 涉及水库沉积速率的定量研究 ${ }^{[5-7]}$ 、事件沉积 ${ }^{[8-9]}$ 、沉积环境变化过程 ${ }^{[10-12]}$ 以及沉积物输移的数值模 拟 ${ }^{[13-16]}$ 等.

利用沉积物指标反映过去环境变化的首要问题是找到沉积物样品对应深度的年代信息. 环境中存在的 放射性核素, 因其特定的来源和地球化学特征, 依据某些年份的沉降通量峰值和沉积物中检测的比活度峰 值, 可应用于沉积物的年代划分. Krishnaswamy 等于 1971 年第 1 次提出 ${ }^{137} \mathrm{Cs}$ 时标计年法 ${ }^{[17]}$, 为短时间尺度 (近 50 年) 的湖泊和水库沉积物的定年和沉积速率研究提供数据 ${ }^{[18]}$, 同时结合沉积岩芯不同深度的多种环 境指标可以反演湖泊和水库自身及周围环境的变迁过程, 从而研究环境的变化与人类活动对湖库及流域的 影响 ${ }^{[19]}$.

石梁河水库是江苏省最大的水库, 自 1962 年建成以来, 在调洪蓄水、保障安全、灌溉农田及促进经济和 社会发展等方面发挥了重要作用, 取得了较大的经济效益和社会效益. 然而, 石梁河水库上游沂沭泗河流域 多低山、丘陵, 植被稀少, 加上不合理的人类活动, 使得该流域土壤侵蚀加剧, 水土流失极为严重, 造成石梁 河水库泥沙淤积严重. 本文结合 ${ }^{137} \mathrm{Cs}$ 计年法和粒度特征来测定石梁河水库沉积物的年龄和沉积速率, 对沉 积速率的环境变化进行解释, 探究水库沉积过程和环境变化的关系, 为石梁河水库的资源开发和环境保护 提供科学依据.

\section{1 材料与方法}

\section{1 研究区概况}

石梁河水库作为江苏省最大的人工水库, 于 1958 年 12 月开工兴建, 1962 年 12 月建成并投人运行, 位 于淮河流域沂沭泗水系新沭河中游, 江苏东海、赣榆及山东临沭三县交界处, 是一座具有防洪、灌溉、供水、 发电、水产养殖、旅游等综合功能的大 (二) 型水库. 石梁河水库的人库流量主要控制站是临沭县大兴镇水文 站, 多年平均径流量为 $20.77 \times 10^{8} \mathrm{~m}^{3}$. 水库集水面积为 $5573 \mathrm{~km}^{2}$, 总库容为 $5.31 \times 10^{8} \mathrm{~m}^{3}$, 其中防洪库容为 $3.23 \times 10^{8} \mathrm{~m}^{3}$, 兴利库容为 $2.34 \times 10^{8} \mathrm{~m}^{3}$. 石梁河水库既是沂沭泗洪水调蓄工程的重要组成部分, 又是连云 港市的重点防洪保安工程和备用水源 ${ }^{[20]}$, 承泄上游沂沭泗流域的洪水, 直接经新沭河排泄人海, 减轻南四 湖、骆马湖的防洪压力及下游周边地区的防洪压力, 并减轻洪水对东部地区的威胁, 提高沂沭泗地区的防洪 标准. 防洪保护范围 2000 余 $\mathrm{km}^{2}$, 主要包括连云港市区、陇海铁路、淮北盐场、田湾核电站、赣愉和东海两县 二十余乡镇约 $6 \times 10^{8} \mathrm{~m}^{2}$ 耕地, 近 150 万人口.

\section{2 样品采集与实验处理}

2005 年 6 月 29 日- 7 月 2 日在石梁河水库进行了为期 4 天的水上作业, 为保证沉积物能够真实反映水 库环境的变化, 选择远离河闸泄洪时可扰动范围和当地民众挖沙区之外进行样品的采集 (图 1). 在距水库泄 洪大坝 $1 \mathrm{~km}$ 处, 利用自制的内径 $70 \mathrm{~mm}$ 、外径 $75 \mathrm{~mm}$ 的 PVC 管重力采样器采集 $200 \mathrm{~cm}$ 长的柱状岩芯 SL8 和 SL9 (34 $\left.46^{\circ} \mathrm{N}, 118^{\circ} 52^{\prime} \mathrm{E}\right)$, 两个柱状岩芯水平相距 $4 \mathrm{~m}$. 为防止样品受到损失和污染, 样品采集后立即在现场 密封保存并运回实验室低温保存. SL8 岩芯以 $4 \mathrm{~cm}$ 间隔分得 50 个样品, 用于 ${ }^{137} \mathrm{Cs}$ 比活度测定; SL9 岩芯以 $2 \mathrm{~cm}$ 间隔分样,用于粒度测定.

SL8 沉积物样品经过真空冷冻干燥器冷冻干燥和玛瑙研针研磨等前期处理后, 采用美国 Caberra 公司生 产的 GMX50P4 同轴高纯锗探测器及多道能谱仪 S-100 进行 ${ }^{137} \mathrm{Cs}$ 比活度的测试, 该实验在南京师范大学同 位素地球化学 ${ }^{137} \mathrm{Cs}$ 实验室完成. SL9 沉积物样品在除去钙质胶结物和有机质等前期处理后, 采用英国 Malvern 公司生产的 Mastersizer 2000 激光粒度分析仪进行粒度测试, 粒径测量范围为 $0.02 \sim 2000 \mu \mathrm{m}$, 重复测量 


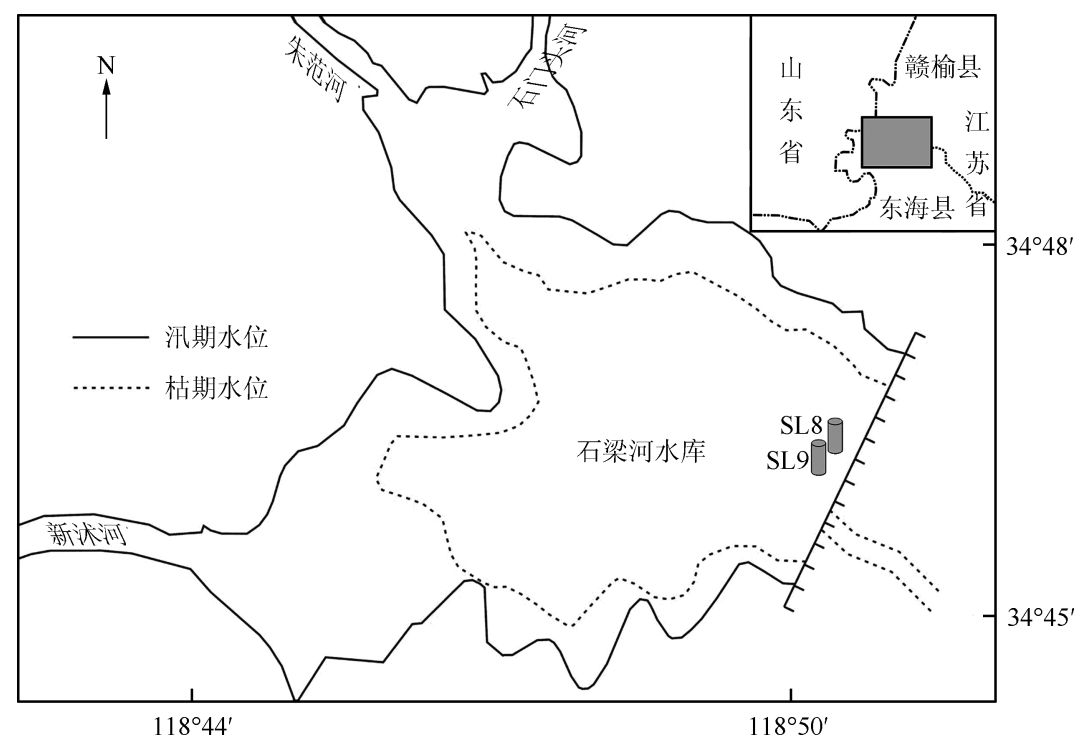

图 1 石梁河水库岩芯位置示意

Fig. 1 Location of the cores in Shilianghe Reservoir

误差小于 $2 \%$,该实验在南京大学海岸与海岛开发教育部重点实验室完成.

\section{2 结果与分析}

\section{1 沉积物粒度变化特征}

观察石梁河水库沉积物岩芯,肉眼看不出明显的粒度变化, 只有底部可以感觉少量的细砂, $0 \mathrm{~cm}$ (岩芯 顶部) 到 $56 \mathrm{~cm}$ 处呈深橄榄色;56 185 cm 呈橄榄灰色;185 cm 向下呈浅橄榄色. 粒度分析结果表明,石梁河 水库岩芯沉积物以黏土质粉砂和粉砂质黏土为主, 砂含量很少 (图 2). 岩芯平均粒径为 $7.3 \Phi$, 中值粒径为 $7.1 \Phi$,两者变化较为一致. 分选系数在 $1.2 \sim 2.0$ 之间, 与平均粒径呈正相关, 粒径越大, 分选系数就越大, 沉积物分选性就越差;反之,粒径越小,沉积物分选性越好.

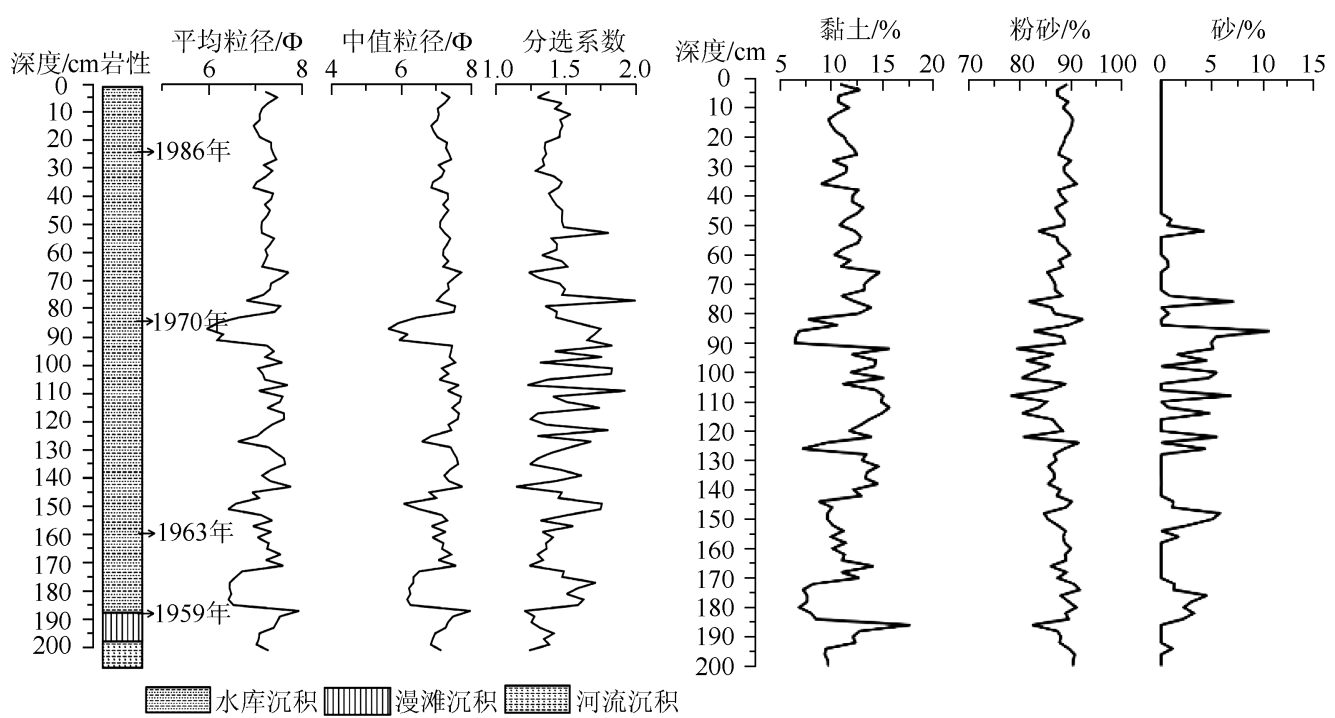

图 2 石梁河水库岩芯粒度参数变化曲线

Fig. 2 The curves of grain size parameters in Shilianghe Reservoir core 
总体上看, 从岩芯底部向上沉积物呈明显的变细趋势, 在 $185 \mathrm{~cm}$ 处向下粒径较小; 从 $185 \mathrm{~cm}$ 向上到 $86 \mathrm{~cm}$ 处, 粒径较大, 分选系数波动性大, 分选性较差; 在 $86 \mathrm{~cm}$ 处有 1 个粒径峰值, 砂的含量也很大, 颗粒较 粗的沉积物能够被搬运; $80 \mathrm{~cm}$ 处向上粒径趋于平稳,有变细的趋势, 分选性波动也较小.

\section{2 沉积物 ${ }^{137} \mathrm{Cs}$ 时标与沉积速率}

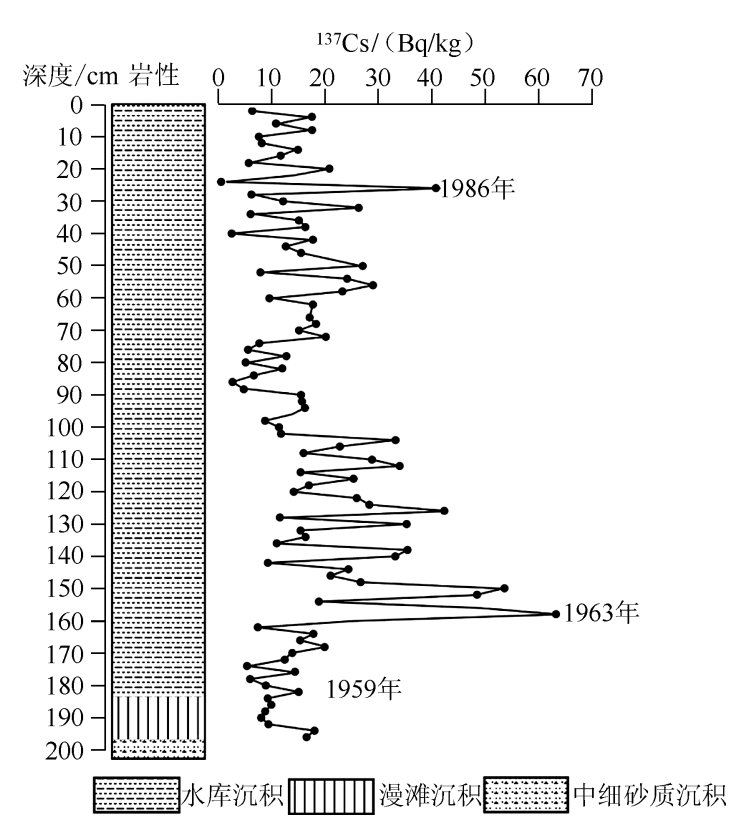

图 3 石梁河水库岩芯 ${ }^{137} \mathrm{Cs}$ 比活度垂直剖面

Fig. 3 The vertical profiles of ${ }^{137}$ Cs activity-depth in Shilianghe Reservoir core
石梁河水库岩芯沉积物样品的 ${ }^{137} \mathrm{Cs}$ 分析结果 表明, ${ }^{137} \mathrm{Cs}$ 放射性比活度随深度变化出现了两个明 显的蓄积峰, 最大蓄积峰值出现在深度 $158 \mathrm{~cm}$ 处, ${ }^{137} \mathrm{Cs}$ 比活度为 $64 \mathrm{~Bq} / \mathrm{kg}$, 另一个蓄积峰值出 现在深度 $25 \mathrm{~cm}$ 处, ${ }^{137} \mathrm{Cs}$ 比活度为 $41.6 \mathrm{~Bq} / \mathrm{kg}$ (图 3 ). 根据 ${ }^{137} \mathrm{Cs}$ 在北半球 50 余年来的蓄积规 律和衰变周期 ( $30.2 \mathrm{a}$ ), 可以初步判定, $158 \mathrm{~cm}$ 处的蓄积峰为 1963 年, $25 \mathrm{~cm}$ 处的蓄积峰可能为 1986 年. 全球范围的 ${ }^{137} \mathrm{Cs}$ 沉降始于 $1950 \mathrm{~s}$ 初, 北 半球沉积物中最早可检测到的 1954 年蓄积峰, 经过衰变, 至今已难以辨识; 1963 年前后大气 ${ }^{137} \mathrm{Cs}$ 沉降量最大, 沉积物 ${ }^{137} \mathrm{Cs}$ 最大峰值对应于 1963 年时标; 1986 年前苏联的切尔诺贝利核泄 漏事件对北半球湖泊沉积物记录存在一定的影 响, 具有同样的时标意义 ${ }^{[21]}$. 这与石梁河水库较 近区域的固城湖、女山湖、南四湖等地区的定年 研究结果一致, 沉积柱芯剖面具有 1963 年和 1986 年的明显双蓄积峰特征 ${ }^{[22-23]}$, 原因可能是 该区域位于太平洋季风区, 地形以平原为主, 所 以有较为明显的 1963 年蓄积峰; 北面没有青藏 高原的阻挡,所以能够在沉积剖面中出现明显的 1986 年蓄积峰.

根据流域汛期降水特征和临沂站洪峰流量的历史资料 ${ }^{[24]}, 1970$ 年 7 月 21 日-8 月 2 日临沂地区发生 特大暴雨, 暴发的山洪不断冲垮塘坝,加上 1968-1970 年林木资源被大面积的肆意破坏(国营、集体林木被 毁 $1.07 \times 10^{8} \mathrm{~m}^{2}$, 树木被砍 1200 万余株), 进一步加剧了流域水土流失. 石梁河水库流域发生的强降水过程 和洪水事件, 伴随着强烈的土壤侵蚀和人库泥沙输送. 结合 SL9 岩芯的粒度分析结果, 可以初步确定 $86 \mathrm{~cm}$ 处粒度参数值出现异常, 反映的可能是 1970 年发生的暴雨和洪水事件. 但需要注意的是, 在 $130 \sim 90 \mathrm{~cm}$ 段 砂的含量较高, 分选系数大, 与 $86 \mathrm{~cm}$ 处相同, 具有显著的阶段性特征, 强降水并不是导致石梁河水库的沉积 泥沙组分发生变化的唯一原因. 利用 ${ }^{137} \mathrm{Cs}$ 蓄积峰位置和洪水事件作为计年时标, 可以计算石梁河水库沉积 岩芯 1963-1970、1970-1986 和 1986-2005 年的平均沉积速率. 1963-1970 年 (158 86 cm) 的沉积速率 为 $10.28 \mathrm{~cm} / \mathrm{a} ; 1970-1986$ 年 $(86 \sim 25 \mathrm{~cm})$ 的沉积速率为 $3.81 \mathrm{~cm} / \mathrm{a} ; 1986-2005$ 年 $(25 \mathrm{~cm}$ 至表层) 的沉积 速率为 $1.32 \mathrm{~cm} / \mathrm{a}$. 虽然 ${ }^{137} \mathrm{Cs}$ 时标法不能给出各层节详细的沉积速率, 只能给出一个阶段的平均沉积速率, 但从计算结果仍可知在过去近 50 年来, 水库沉积速率整体上经历了一个由快到慢的过程.

\section{3 讨论}

\section{1 泥沙来源与水库淤积}

水库的来水来沙、坝前水位的变化及地形条件等, 决定了泥沙运动, 因而也决定了水库淤积形态. 已有 研究资料表明, 在水库淤积的三角洲、雉体、带状淤积体等 3 种剖面形态中, 三角洲淤积体是最普遍的, 也是 水库在淤积过程中的基本倾向 ${ }^{[25-26]}$.

石梁河水库中上游地区为鲁南山区的沂沭泗河流域, 周围地势总体来说呈西北高、东南低. 西北部为低 
山、丘陵和岗地; 中部、东部和东南部是大面积的冲积平原. 由于全区植被覆盖率较低、质地松散及降水集中 等环境特点, 导致碎屑沉积物抗蚀性差, 河流夹砂和冲刷力强, 使得水土流失相当严重. 利用 DEM 数字高程 模型进行估算的结果表明 ${ }^{[27]}$, 沂河流域平均侵蚀量约为 $1166175 \mathrm{~m}^{3}$, 平均侵蚀模数为 $603 \sim 724$ $\mathrm{t} /\left(\mathrm{km}^{2} \cdot \mathrm{a}\right)$, 多年平均输沙量为 $4 \times 10^{6} \mathrm{t}$. 石梁河水库库底有 2 条原河道的槽沟, 人库的水沙基本上沿着原 河道流向库首, 且粗颗粒物质的沉积先于细颗粒物质,致使河水携带的泥沙在库尾不断淤积. 北边支流的流 量小、比降缓和, 多年泥沙淤积厚度在 $0.1 \sim 0.5 \mathrm{~m}$ 之间. 从大兴镇人库的新沭河来沙量较大, 在洪水季节河 流携带大量推移质的粗砂、极粗砂和岩屑, 当流水携沙处于超饱和状态时, 推移质首先落淤, 沿着老的新沭 河库底河道, 由库尾逐步向库首移动发展,形成水下三角洲 (图 4). 在库底老河道两岸, 不断淤积加厚、扩大 三角洲的规模; 同时在重力的作用下, 新的三角洲又迭加于老三角洲前坡上 ${ }^{[28]}$. 沿着原河道两岸, 库内泥沙 淤积厚度最厚处已达 $4.3 \mathrm{~m}$, 从库尾到库首淤积厚度峰值有: $3.4 、 4.0 、 4.3 、 4.0 、 3.3$ 和 $3.0 \mathrm{~m}$, 都是一个个三 角洲沿着老河道迭瓦状向库首推进,而形成的每个三角洲洲面淤积的高度值.

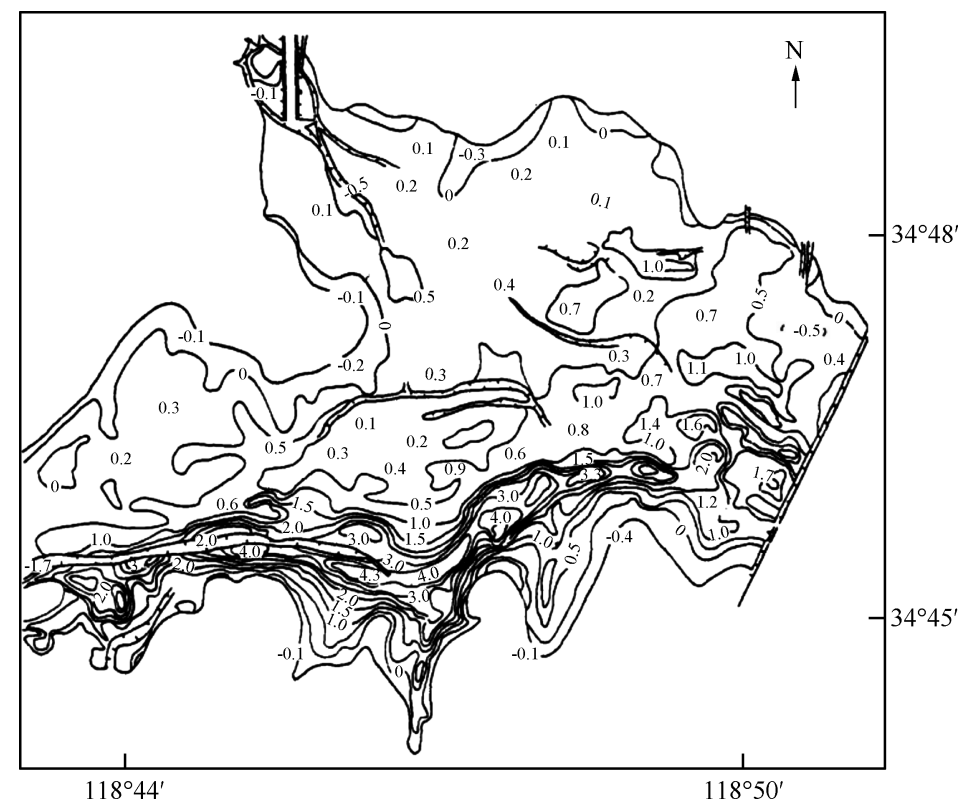

图 4 石梁河水库淤积厚度等值线 (单位: $\mathrm{m}$ )

Fig. 4 Silt thickness contour of Shilianghe Reservoir

石梁河水库的淤积, 除了丰富的泥沙来源, 还与人库河流的流量、流速和比降等水动力条件有关. 石梁 河水库沉积物以黏土质粉砂和粉砂质黏土为主,砂含量很少. 在 $185 \mathrm{~cm}$ 处向下为建库以前的河漫滩一河流 相沉积, 粒径较小; 从 $185 \mathrm{~cm}$ 向上到 $86 \mathrm{~cm}$ 处为建库后一段时期内的水库沉积, 粒径较大, 分选系数波动性 大, 分选性较差; 在 $86 \mathrm{~cm}$ 处左右有 1 个粒径峰值, 砂的含量也很大, 说明该时期水动力很强, 能够搬运较粗 的沉积物; $80 \mathrm{~cm}$ 处向上粒径趋于平稳,有变细的趋势, 分选性波动也较小. 泥沙在水库中淤积的过程是, 当 水沙进人库尾时,粗沙首先沉积下来, 逐渐形成三角洲; 同时异重流挟带着细沙向坝前推进, 并沿途不断扩 散, 这样细沙将沉积在整个水库范围内, 其中大部分沉积在坝前, 由于水库回水的影响, 在水库库尾以上的 河道内也会发生泥沙淤积.

\section{2 水库沉积与流域降水的关系}

沉积物粒度组成特点直接反映了沉积时的降水、水动力搬运强度以及水位高低变化等信息 ${ }^{[29]}$. 在长尺 度、低分辨率(百年、千年) 的沉积环境中,粗粒沉积物反映低水位时期的干旱气候, 细粒沉积物反映高水位 时期的湿润气候 ${ }^{[30]}$. 然而对于中短尺度、高分辨率 (年际、几十年) 的湖泊或水库来说, 在过去几十年间可能 并不存在水位的大幅度涨落, 水位变化对粒度分布的影响很小, 流域降雨量的变化通过影响地表径流强度 
在相当程度上决定着进入湖库的碎屑物质的粗细和含量, 进而影响沉积物粒度 ${ }^{[31]}$. 山西汾河水库随着上游 降水量的减少, 人库径流量呈明显减少趋势 ${ }^{[32]}$; 北京密云水库由于极端降水事件, 尤其是 1991、1994 和 1998 年发生的特大暴雨导致强度的侵蚀产沙作用, 流域产沙量明显增加 ${ }^{[33]}$.

石梁河水库上游区域属暖温带半湿润季风气候区,春季(3、4、5 月)、夏季 $(6 、 7 、 8$ 月)、秋季 $(9 、 10 、 11$ 月) 和冬季 (12、1、2 月) 降雨量分别占全年降雨量的 $15 \% 、 63 \% 、 17 \%$ 和 5\%, 汗期降水量占全年的 79\%, 年 内降水分配不均 ${ }^{[34]}$. 在夏季的高温期, 如遇北方冷空气的顶托, 极易形成暴雨, 且该区域的土层疏松, 岩石破 碎, 植被的覆盖率低, 暴雨出现后水土流失严重, 导致人库泥沙量剧增. 将石梁河水库的粒度沉积记录和流 域降水记录进行对比发现 (图 5), 在 1980s 之前, 石梁河水库沉积的粗颗粒物质和降雨量的变化趋势基本相 同,1980s 至今, 虽然降水变化波动很大, 但沉积物粒径变化幅度很小; 粒径大于 15 和 $32 \mu \mathrm{m}$ 的沉积物含量 出现明显的峰值,且含量变化与降雨量的变化趋势基本相同.

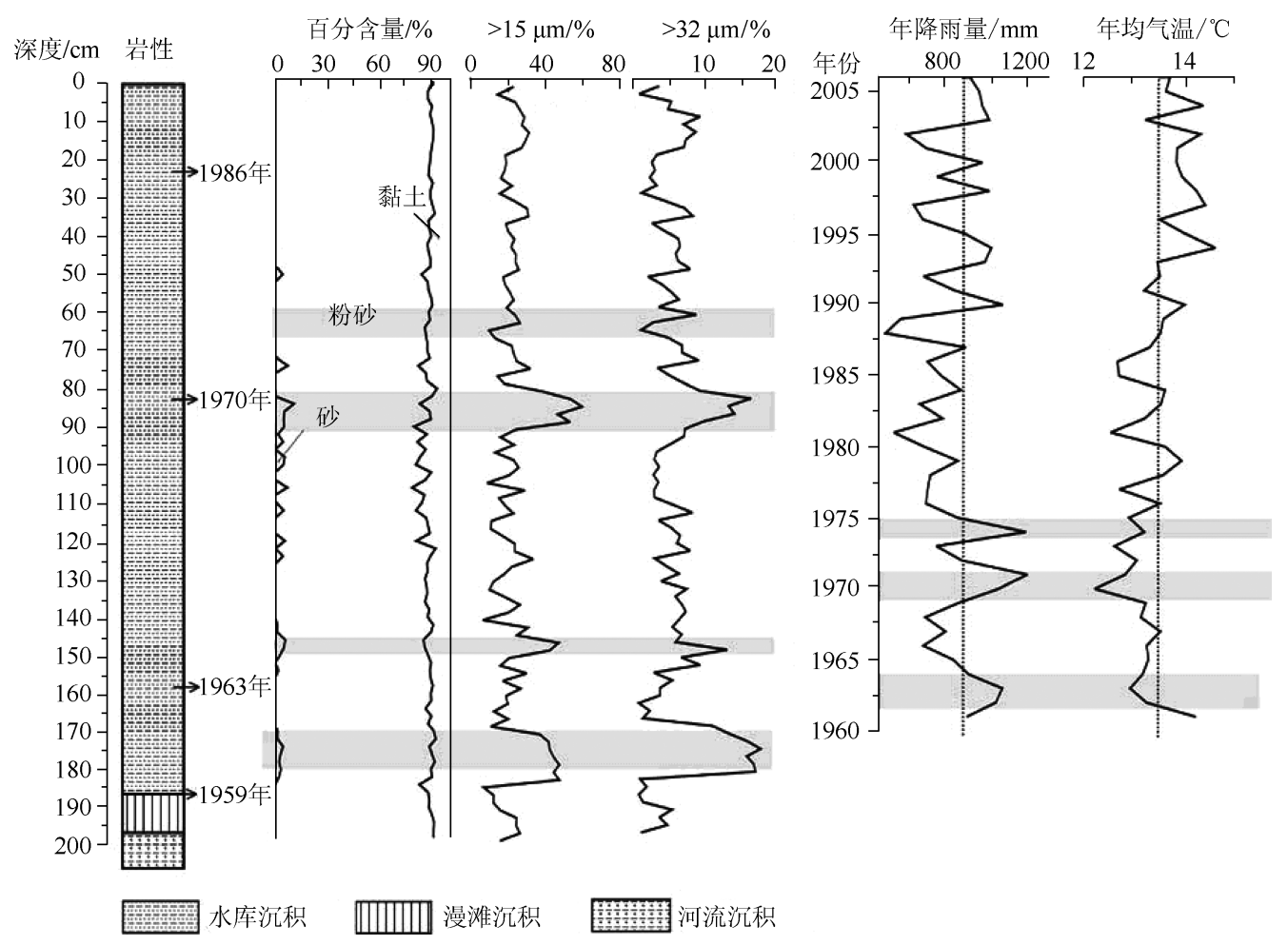

图 5 石梁河水库沉积物粒度含量变化和临沂市降水、气温变化

Fig. 5 The grain composition in Shilianghe Reservoir core, precipitation and temperature changes in Linyi City

沉积物粒度的变化主要受水动力条件制约, 而水动力条件往往受气候环境变化的影响, 气候变化最直 接的反映就是气温和降水. 因而, 气温和降水变化必然影响到人库补给水动力的大小和水面高低, 进而影响 沉积物粒度分布. 在我国东部季风区, 一般冬季低温少雨, 夏季高温多雨, 由降水形成的洪水和地表径流直 接影响沉积物的颗粒大小, 占主导地位. 根据临沂市降水变化的历史记录可知 ${ }^{[35]}, 1970 \mathrm{~s}$ 前中期为多雨期, 1970 年发生特大暴雨, 地表径流增强, 水体剥蚀和搬运能力强, 大量陆源粗颗粒物质被带至库区沉积, 形成 了岩芯 $86 \mathrm{~cm}$ 左右处粒度与其它沉积层显著不同的洪水事件沉积层, 颗粒较粗, 以粉砂为主. 但是, 根据石梁 河水库沉积岩芯 $130 \sim 90 \mathrm{~cm}$ 段泥沙组分含量的阶段性变化特征, 说明沉积水动力波动复杂, 不仅受到强降 雨因素的影响, 还可能与上游修建的大官庄水利枢纽等工程定期的泄洪排沙有关, 需要根据上游水库可持 续管理的历史资料和实测数据进一步深人分析. 为保持水库的长期使用, 充分利用水库的泄流排沙, 将淤积 的泥沙冲到下游, 是加强水库管理的重要措施. $1980 \mathrm{~s}$ 至今, 虽然降水变化波动很大, 但沉积物粒径变化幅度 
很小. 原因可能是上游修建的水库有效拦截了粗颗粒沉积物. 石梁河水库上游沂河、沭河均为山洪河道, 流 域上游大型水库众多 ${ }^{[36]}$, 沂河临沂站上游建有田庄、跋山、岸堤、许家崖、唐村 5 座大型水库, 总控制流域面 积为 $4316 \mathrm{~km}^{2}$, 总库容为 $18.4 \times 10^{8} \mathrm{~m}^{3}$. 沭河大官庄站上游建有沙沟、青峰岭、小仕阳、陡山 4 座大型水库, 总 控制流域面积为 $1482 \mathrm{~km}^{2}$, 总库容为 $9.2 \times 10^{8} \mathrm{~m}^{3}$. 流域中上游大量修建的水库能够有效拦截河流输沙量,使 得河流人海泥沙呈减少趋势 ${ }^{[37-38]}$. 我国黄河流域河流输沙量的 $70 \%$ 被三门峡和小浪底水库所拦截 ${ }^{[39]}$. 石梁 河上游修建的众多水库,形成水动力较弱的低能沉积环境, 粗颗粒泥沙优先于细颗粒泥沙沉积, 经过层层篮 选,使得进人石梁河水库的泥沙分选性较好,沉积物颗粒大小均匀一致.

\section{4 结论}

水库淤积现象普遍存在, 由于泥沙的淤积, 使得水库有效库容逐年减少, 蓄水调节性能降低, 对水库上 游工程造成不利影响, 同时威胁沿河两岸工农业生产的安全, 还会引起河道冲刷下降,给水库的管理造成一 定的困扰. 石梁河水库岩芯沉积物的粒度变化特征记录了区域环境变化的信息. 石梁河水库上游沂沭泗河流 域植被稀少,质地松散,在河流夹砂和强冲刷力作用下,抗蚀性差的碎屑沉积物质成为水库淤积的主要物质来 源. 石梁河水库的来水来沙、坝前水位变化和地形等条件,使得水库剖面形态呈典型三角洲淤积. 流域降水量 的变化决定着人库泥沙的粗细和数量,进而影响沉积物粒度变化特征. 根据 ${ }^{137} \mathrm{Cs}$ 放射性同位素存在的蓄积 峰, 初步推算, 2 个蓄积峰分别对应 1963 年和 1986 年, 这与石梁河水库附近固城湖、女山湖、南四湖等地区 的沉积物定年研究的结果一致. 结合沉积物粒度的洪水事件和采样日期,推算出石梁河水库的平均沉积速 率分别为: $1963-1970$ 年为 $10.85 \mathrm{~cm} / \mathrm{a}, 1970-1986$ 年为 $3.81 \mathrm{~cm} / \mathrm{a}, 1986-2005$ 年为 $1.32 \mathrm{~cm} / \mathrm{a}$. 沉积速率 变化表明石梁河水库沉积符合水库淤积的一般规律,1970s 以前,在植被稀少、坡陡水急、强降水等因素综合 作用下,泥沙来源丰富, 沉积速率较大. 1980s 以来,水库淤积减缓,淤积速率较小, 原因可能是上游大官庄等 水利枢纽工程的建设,拦坝蓄水,水位抬高,河床比降变缓,流速降低,来沙量逐渐减少.

\section{5 参考文献}

[1] 韩其为,杨小庆. 我国水库泥沙淤积研究综述. 中国水利水电科学研究院学报,2003,1(3):169-178.

[2]田海涛,张振克,李彦明等. 中国内地水库淤积的差异性分析. 水利水电科技进展,2006,26(6):28-33.

[ 3 ] 吕明辉,王红亚, 蔡运龙. 基于湖泊(水库)沉积物分析的土壤侵蚀研究. 水土保持通报,2007,27(3):36-41.

[ 4 ] Annandale GW. Reservoir sedimentation: Developments in water science. Netherlands: Elsevier, 1987.

[ 5 ] Ionita I, Margineanu RM, Hurjui C. Assessment of the reservoir sedimentation rates from ${ }^{137}$ Cs measurements in the Moldavian Plateau. Actageológicahispánica, 2000, 35(3/4) : 357-367.

[6] 王文博, 蔡运龙, 王红亚. 结合粒度和 ${ }^{137} \mathrm{Cs}$ 对小流域水库沉积物的定年一一黔中喀斯特地区克酬水库为例. 湖 泊科学, 2008,20 (3) : 306-314.

[ 7 ] 李春梅, 王红亚. 贵州省西南部麦岗水库沉积物的 ${ }^{137} \mathrm{Cs}$ 和 ${ }^{210} \mathrm{~Pb}$ 测年与沉积速率研究. 水土保持通报, 2010,30 (2) $: 215-219$.

[ 8 ] Ambers RKR. Using the sediment record in a western Oregon flood-control reservoir to assess the influence of storm history and logging on sediment yield. Journal of Hydrology, 2001, 244(3/4) :181-200.

[ 9 ] Lee HY, Lin YT, Chiu YJ. Quantitative estimation of reservoir sedimentation from three typhoon events. Journal of Hydrologic Engineering, 2006, 11(4) : 362-370.

[10] Rowan JS, Price LE, Fawcett CP et al. Reconstructing historic reservoir sedimentation rates using data-based mechanistic modelling. Physics and Chemistry of the Earth, Part B : Hydrology, Oceans and Atmosphere, 2001, 26(1) : 77-82.

[11] Nagle GN. The contribution of agricultural erosion to reservoir sedimentation in the Dominican Republic. Water Policy, $2002,3(6)$ : 491-505.

[12] 文安邦,张信宝, 李 豪等. 云南楚雄九龙甸水库沉积剖面 ${ }^{137} \mathrm{Cs} 、{ }^{210} \mathrm{~Pb}$ 和细粒泥沙含量的变化及其解译. 泥沙研 究, 2008,53(6): 17-23.

[13] Hernandez P, Ambrose RB, Prats D et al. Modeling eutrophication kinetics in reservoir microcosms. Water Research, 1997, 31(10): 2511-2519.

[14] De Cesare G, Schleiss A, Hermann F et al. Impact of turbidity currents on reservoir sedimentation. Journal of Hydraulic 
Engineering, 2001, 127(1): 6-16.

[15] 韩其为,何明民. 水库淤积与河床演变的 (一维) 数学模型. 泥沙研究, 1987,32(3):17-23.

[16] 许飞,李永业,阎庆绂等. 耿庄水库泥沙沉积分析模型试验研究. 山西水利,2011, (1):35-37.

[17] Krishnaswamy S, Lal D, Martin JM et al. Geochronology of lake sediments. Earth and Planetary Science Letters, 1971,11 (1-5) : 407-414.

[18 ] Ritchie JC, McHenry JR. A comparison of three methods for measuring recent rates of sediment accumulation. Journal of the American Water Resources Association, 1985, 21 (1) : 99-104.

[19] 何清平, 吴 宇. 湖泊、水库沉积物年代的 ${ }^{210} \mathrm{~Pb}$ 与 ${ }^{137} \mathrm{Cs}$ 确定方法. 矿物岩石地球化学通讯, 1990,10(3):208-210.

[20］连云港市水利局. 石梁河水库库区综合整治规划报告. 2005.

[21] 张 燕,潘少明,彭补拙. 用 ${ }^{137} \mathrm{Cs}$ 计年法确定湖泊沉积物沉积速率研究进展. 地球科学进展,2005,20(6):671-678.

[22] 项 亮, 王苏民,薛 滨. 切尔诺贝利核事故泄漏在苏皖地区湖泊沉积物中的蓄积及时标意义. 海洋与湖沼, 1996, 27 (2) :132-137.

[23] 杨丽原, 沈 吉, 张祖陆等. 近四十年来山东南四湖环境演化的元素地球化学记录. 地球化学, 2003, 32 (5): 453-460.

[24] 詹道强. 沂沭泗流域汛期降水特征与临沂站洪峰流量的对比分析. 水科学进展,2000,11(3):88-91.

[25] 韩其为. 论水库的三角洲淤积 (一). 湖泊科学, 1995,7(2):107-118.

[26] 韩其为. 论水库的三角洲淤积 (二). 湖泊科学, 1995,7(3):214-225.

[27] 孙希华, 姚孝友, 周 虹等. 基于 DEM 的山东沂沭泗河流域地貌演化与水土流失研究. 水土保持通报,2005,25 (4) :24-28.

[28］陈月秋. 石梁河水库自然地理概况与泥沙淤积特征. 湖泊科学, 1992,4(3):69-77.

[29］殷志强,秦小光, 吴金水等. 湖泊沉积物粒度多组分特征及其成因机制研究. 第四纪研究, 2008,28(2):345-353.

[30 ] Wang H, LiuH, Cui H et al. Terminal Pleistocene/Holocene palaeoenvironmental changes revealed by mineral-magnetism measurements of lake sediments for Dali Nor area, southeastern Inner Mongolia Plateau, China. Palaeogeography, Palaeoclimatology, Palaeoecology, 2001, 170(1/2) : 115-132.

[31] 陈敬安, 万国江, 张 峰等. 不同时间尺度下的湖泊沉积物环境记录一一沉积物粒度为例. 中国科学: D 辑: 地球 科学, $2003,33(6): 563-568$.

[32] 胡彩虹,管新建, 吴泽宁等. 水土保持措施和气候变化对汾河水库人库径流贡献定量分析. 水土保持学报,2011,25 (5) $: 12-16$.

[33] 李子君, 李秀彬, 朱会义等. 降水变化与人类活动对密云水库人库泥沙量的影响. 北京林业大学学报, 2008,30(1): 101-107.

[34] 陈钰文,项 瑛. 江苏省水库 50a 气候变化与水资源特征分析. 第六届长三角气象科技论坛论文集, 2009:44-49.

[35］詹道强. 沂沭泗流域汛期降水特征与临沂站洪峰流量的对比分析. 水科学进展,2000,11(3):88-91.

[36] 张世功,孙廷胥, 刘福学等. 沂沭河流域大型水库至下游控制站河道流量演算方案研究. 水文, 2009,29(5):50-54.

[37] Walling DE. Human impact on land-ocean sediment transfer by the world's rivers. Geomorphology, 2006, 79(3/4) : 192216.

[38 W Walling DE, Fang D. Recent trends in the suspended sediment loads of the world's rivers. Global and Planetyar Change, $2003,39(1 / 2): 111-126$.

[39］张振克,陈云增, 田海涛等. 黄河流域水库拦截泥沙量的计算及泥沙分布特征. 中国水土保持,2008,(4):20-22. 